Article

\title{
AgriTech Innovators: A Study of Initial Adoption and Continued Use of a Mobile Digital Platform by Family-Operated Farming Enterprises ${ }^{\dagger}$
}

\author{
Grace Fox ${ }^{1 \oplus}$, John Mooney ${ }^{2}\left(\mathbb{D}\right.$, Pierangelo Rosati $^{1, *}$ ) and Theo Lynn ${ }^{1}(\mathbb{D}$ \\ 1 Irish Institute of Digital Business, Dublin City University, Collins Avenue, D09 Y5N0 Dublin, Ireland; \\ grace.fox@iidb.ie (G.F.); theo.lynn@dcu.ie (T.L.) \\ 2 Pepperdine Graziadio Business School, Pepperdine University, 24255 Pacific Coast Hwy, \\ Malibu, CA 90263, USA; john.mooney@pepperdine.edu \\ * Correspondence: pierangelo.rosati@dcu.ie \\ + The present work is an extension of the paper "Towards an Understanding of Farmers' Mobile Technology \\ Adoption: A Comparison of Adoption and Continuance Intentions" presented to the 24th Americas \\ Conference on Information Systems, New Orleans, LA, USA, 16-18 August 2018.
}

check for updates

Citation: Fox, G.; Mooney, J.; Rosati, P.; Lynn, T. AgriTech Innovators: A Study of Initial Adoption and Continued Use of a Mobile Digital Platform by Family-Operated Farming Enterprises. Agriculture 2021, 11, 1283. https://doi.org/10.3390/ agriculture11121283

Academic Editors: Johannes Sauer and Sanzidur Rahman

Received: 9 October 2021

Accepted: 13 December 2021

Published: 16 December 2021

Publisher's Note: MDPI stays neutral with regard to jurisdictional claims in published maps and institutional affiliations.

Copyright: (c) 2021 by the authors. Licensee MDPI, Basel, Switzerland. This article is an open access article distributed under the terms and conditions of the Creative Commons Attribution (CC BY) license (https:// creativecommons.org/licenses/by/ $4.0 /)$.

\begin{abstract}
While information technology is playing a significant transformative role in virtually every industry, within the agriculture sector, family-operated farming enterprises have been slow to adopt IT solutions to manage their operations. This study adopts a sequential mixed-methods research design to examine the pre- and post-adoption phases of farmers' use of a mobile digital platform for farm management. Our findings show that farmers' initial acceptance of a mobile digital platform for farm management is shaped by social influence, which mediates the impact of performance and effort expectancy. Post-adoption continued use of the digital platform is influenced directly by performance and effort expectancy and indirectly by trust beliefs and social influence. Perceived work impediment indirectly influences post-adoption acceptance via effort expectancy. Our study untangles the direct and indirect influences of positive and negative perceptions on farmers' acceptance of a new innovative AgriTech digital platform in these different phases.
\end{abstract}

Keywords: AgriTech; mobile platform adoption; continuance behavior; mixed methods

\section{Introduction}

Adoption and diffusion of digital technologies have attracted a large volume of interest across the disciplines of management and information systems. The increasing complexity of technological innovations in recent years heightens the importance of understanding the dynamics surrounding adoption of digital products and services [1]. Furthermore, the long-term success of technology companies is contingent upon customers' continued use of their products [2]. While there is a large body of literature that examines how and why technological innovations are adopted [3], many gaps in our understanding persist. First, in the sphere of understanding the initial adoption decision, some contexts remain under-examined and there exists a bias towards the positive factors influencing adoption [3]. Second, research investigating behaviors after initial adoption remains lacking [4], particularly in the context of subscription-based services [2].

Like many small- and medium-sized businesses, family-owned farming enterprises around the world have lagged in both the deployment and adoption of digital technologies for a variety of reasons, including physical, cultural, locational, and attitudinal issues [5] as well as cost issues [6]. Recent studies suggest that despite significant increases in penetration of Information Technology (IT) within family-owned farming enterprises, there remains a digital divide between actual use of IT when compared with the mainstream business community and the general population [7]. Despite seminal research being inspired and focusing on the diffusion and adoption of agricultural technologies [8], there 
exists a paucity of technology adoption studies that shed light on farmers initial adoption and on-going usage behaviors of digital platforms that assist with farm management. This gap requires exploration given the significant economic importance of agriculture in most countries around the world. In addition, increasingly rigorous food safety requirements imposed by regulatory authorities, combined with growing consumer preferences for food provenance (e.g., "farm to table" business models) require farmers to collect ever-increasing quantities of very precise and accurate data. Thus, the potential and importance of real-time digital platforms for farm management is growing.

Our research study seeks to understand technology adoption in the context of a mobile, cloud-based digital platform for farm management by family-operated farming enterprises in Ireland. Even though mobile applications offer affordable, convenient, easyto-use solutions for tracking data, farmers who run small family-owned farms-which account for the vast majority of farming enterprises in Ireland [3] — have historically resisted technology adoption $[9,10]$ and continue to record and process data manually. However, most farmers now carry smart phones, which offer an opportunity to shift farm data management to a mobile, real-time digital platform. In order to encourage the initial adoption and sustained usage of mobile digital platforms to enhance farm management, this paper explores the following research questions:

RQ1. What factors positively and negatively influence farmers' initial decision to adopt a mobile digital platform for farm management?

RQ2. What factors influence farmers' continued use of a mobile digital platform for farm management?

To explore these questions, this study employs an explanatory sequential mixedmethods design [11]. The first stage of the study was exploratory, consisting of two focus groups, one with current users of the mobile application and the other with non-users.

The remainder of the paper proceeds with a brief overview of the technology adoption literature. The findings from the focus groups are presented along with the proposed research models. The quantitative findings are then discussed. The paper concludes with a discussion of the contributions, limitations, and directions for future research.

\section{Literature Review and Theoretical Background}

Early technology adoption and diffusion research focused either on the individual characteristics of the adopter or the characteristics of the innovation itself [12]. It can be argued that a sole focus on the categorization of individuals according to the point at which they adopt the innovation remains useful when examining the diffusion of an innovation in a specific market. However, this approach is less relevant today given that the adoption process is more complex than a discrete decision whether or not to adopt. Furthermore, in some contexts such as farming, it can be argued that the large majority of potential adopters would be categorized as laggards. The focus on the characteristics of the innovation as detailed by Rogers [12] in his diffusion of innovations theory has evolved in recent years towards a broader focus on how an individual's perceptions about the innovation influence their adoption decisions.

\subsection{Technology Adoption Literature}

Since the 1980s, researchers have been engaged in research efforts that seek to explain the factors that contribute to technology adoption, which have culminated in a welldeveloped stream of literature [13]. This body of knowledge is comprised of a number of validated models that can be combined to summarize the technology adoption process in three stages: Individuals' experiences, intentions, and actual use of technology [14]. The majority of these models leverage the Theory of Reasoned Action (TRA), which has been applied to predict a range of behaviors across disciplines and contexts. TRA posits that individuals' attitude toward adoption is influenced by their salient beliefs [15]. These beliefs can include descriptive beliefs formed from direct experience, inferential beliefs 
based on past experiences, and informational beliefs based on information from external sources such as peers or family members [16]. This attitude coupled with subjective norms or the individual's perception of how referent others will view this behavior, lead to the emergence of behavioral intention [16]. TRA postulates that behavioral intention will lead to the performance of the behavior.

TRA was first extended to the technology adoption context by Davis [17] in his Technology Acceptance Model (TAM). TAM is one of the most widely applied and adapted technology adoption models in the literature [13]. Under TAM, technology adoption is determined by behavioral intention, which in turn is influenced by attitude towards the technology; attitude is developed based on the individual's beliefs as is the case in TRA. These beliefs are not predetermined in TRA. However, TAM posits that attitude is influenced by the Perceived Ease of Use (PEOU) and Perceived Usefulness of the technology (PU) (Davis, 1993). PU is defined as an individual's perception of how use of the technology can improve job performance [17]. PEOU relates to the individual's perception that use of the technology will be free from effort (Davis, 1989). Another model developed using TRA is the Theory of Planned Behavior (TPB) [15]. TPB posits that adoption intention is influenced by attitude toward adoption, subjective norms, and perceived behavioral control described as the individual's perceptions of how easy or difficult it would be for them to perform the behavior [15]. Individuals' behavior is then influenced both by perceived behavioral control and intention.

The prevailing technology adoption models including TRA, TAM, TPB, and others were retested and amalgamated by Venkatesh et al. [14] to create the Unified Theory of Acceptance and Use of Technology (UTAUT). UTAUT proposes that performance expectancy, effort expectancy, social influence, and facilitating conditions influence behavioral intention and actual use. Performance expectancy can be compared to PU and is the strongest predictor of intention [14]. Effort expectancy is similar to PEOU. Social influence is based on subjective norms [14]. Facilitating conditions pertains to the individual's beliefs regarding whether use of the technology is supported within the organization or community. According to UTAUT, intention is directly influenced by performance expectancy, effort expectancy, and social influence, with actual use predicted by behavioral intention and facilitating conditions. TAM and UTAUT have been applied across a number of contexts to understand employees' and consumers' technology adoption and extended to include various constructs from trust to privacy risk (e.g., [18]). Among the dominant technology adoption models, the following constructs are repeatedly present: Perceived ease of use or effort expectancy, perceived usefulness or performance expectancy, and Social Influence (SI).

\subsection{Post-Adoption Behaviors}

In recent years, researchers have acknowledged the fact that initial adoption of a technology may not lead to ongoing continued usage [19]. This has resulted in a shift in focus towards understanding individuals' behaviors after the initial adoption of a new technology, often with an emphasis on understanding why individuals discontinue use [20,21]. It is very important for technology providers to understand post-adoption behavior as the acquisition of new customers has been estimated to cost as much as 5 to 8 times the cost of retaining existing customers [4]. To understand individuals' intentions to continue or discontinue use, Recker [21] combined positive beliefs regarding system use, namely constructs popularized in technology adoption models such as PU and PEOU, with negative beliefs such as perceived work impediment associated with use of the technology and perceived costs of use. The limited research on post-adoption behaviors offers support for the influence of individuals' perceptions after adoption on their post-adoption behaviors, with perceived usefulness and perceived ease of use positively impacting continuance of technology use in contexts such as mobile services [4]. We propose that negative beliefs are relevant when exploring continuance intentions of farmers but are also pertinent when exploring farmers' initial adoption intentions, as the negative perceptions associated with 
individuals' current practices are likely to influence their intentions to adopt a digital platform as an alternative.

\subsection{Information Technology Adoption in Agriculture}

Over the last three decades, numerous studies have explored information technology adoption by farmers, initially focusing on computer and internet adoption [22]. The dual use of computer and internet technologies in family-operated farms, which are both businesses and households, combined with the heterogeneous nature of farm business activities poses both challenges and fruitful avenues for research (see e.g., [23]). Over time, studies have expanded beyond mere hardware and network access to explore behaviors [24], purchasing patterns [23], and specific software applications and use cases e.g., farm management information systems [25], and financial systems [26], etc. Significant themes explored within this literature include the individual characteristics of farmers such as age [27], education [28], farming experience [29], and the characteristics of farmer spouses [23]. A recent study adapted TAM to explore adoption of grassland budgeting software and financial systems among new entrant dairy farmers and found support for the positive influence of perceived usefulness and perceived ease of use on adoption [26]. Another study adopted a qualitative approach to investigate the role of emotion in influencing dairy farmers' adoption of innovations in a broader sense [3].

Notwithstanding the rich extant literature on the adoption of IT by farmers generally and studies of adoption of mobile technologies in general (e.g., [4,30]), there remains a paucity of research that examines mobile technology adoption and post-adoption behaviors among family-operated farming enterprises. There is a need for research that explores the positive and negative factors that influence farmers' decisions to initially adopt and continue the use of digital platforms.

\section{Study Background: Importance of Agriculture in Ireland}

Agriculture represents an important sector to the Irish economy, contributing over $€ 10$ billion in exports and accounting for approximately 269,500 people working on 139,600 family farms [3,31]. As noted recently by Hennessy et al. [7], while farmers increasingly have access to computers and the internet, farmers' usage rates for computers and internet access remains quite low compared to the general population and other sectors. They also note that while computers are more likely to be used on larger dairy farms, farmers operating small, non-dairy farms are unlikely to use computers for farm management.

Low IT access and usage rates pose public policy challenges. Increasingly, rigorous food safety requirements imposed by regulatory authorities, combined with growing consumer preferences about food provenance, requires farmers to collect ever-increasing quantities of data, thus increasing the importance of IT solutions within this industry. For instance, farmers in Ireland must comply with a number of stringent food safety requirements related to traceability and quality assurance that include tracking all animal movements, medicines administered, pesticides, and other spray treatments applied. Larger farms typically have the scale, resources, and expertise to exploit IT and dedicate professional IT staff to assist with deploying appropriate systems to capture and manage this data [7]. However, most Irish farms are small, family-owned and operated, and lack these resources and capabilities. Mobile technologies offer promises of greater affordability, ease of use, and convenience compared with traditional "enterprise" IT systems, and a potentially valuable digital platform for family-operated farms. Despite the emergence of mobile digital platforms that enable farmers to digitally collect and process all required data, adoption remains low [9].

The technology of interest in this study is a mobile digital platform for farm management currently used by over 5000 farmers in Ireland. The cloud-based mobile application costs $€ 130$ per year, is available on iOS and Android mobile phone and tablet devices, and is compatible with laptops and PCs. The mobile application allows farmers to digitally record "on the go" all operational data required to meet their statutory obligations under 
various government schemes for food safety, then synchronize data when internet connectivity is available. The application's features include recording animal movements, remedy tracking, breeding data, spray data, storage and retrieval of data, and generating reports required for audits.

\section{Focus Groups}

The first stage of the research was exploratory with focus groups chosen as the appropriate method to develop insights into the technology experience of farmers, their requirements, and the factors positively and negatively influencing their adoption or subsequent usage. Two focus groups were conducted, the first with eight members of the farming community currently using the technology (hereafter the 'user group') and the second with seven members of the farming community currently tracking all data manually (hereafter the 'non-user group'). Both focus groups included participants of both genders, of varied ages, and differing levels of technology experience. An interview guide (see Appendix A.1) was developed based on the seminal technology adoption literature with open-ended questions to explore the relevance of each core technology adoption construct. These included perceptual constructs such as usefulness, ease of use, social influence, and behavioral constructs such as current technology use behaviors and intended future behaviors. Both focus groups were conducted by the same two researchers, audio-taped and transcribed. Thematic analysis was conducted to explore the relevance of all constructs for users and non-users (see Appendix A.2) and to combine with existing literature to develop the two research models.

\section{Qualitative Findings and Research Models}

The qualitative transcripts were analyzed to explore the relevance of positive and negative factors discussed in the technology adoption and continuance literature. Each factor is briefly discussed with key findings from the focus groups highlighted. Subsequent hypothesized relationships are then presented.

\subsection{Positive Perceptions}

In terms of positive perceptions, the existing literature offers strong support for the influence of Performance Expectancy (PE) on Effort Expectancy (EE) adoption and continuance intention [21]. The relevance of these factors was also supported in the focus groups with users and non-users. In terms of effort expectancy, non-users discussed their limited technical competence and stated they "would need to be comfortable using it". Upon viewing the mobile application, participants were pleasantly surprised at how easy it seemed to use with one participant noting "I knew they had the app, but I didn't know if it is easy enough to use or if it takes all day to put in the information. It seems easy". Ease of use had a clear link with willingness to adopt the digital platform as evidenced in statements such as "it would need to be very straight forward for me to use it". In the user focus group, all participants noted that they found the mobile application surprisingly easy to use, sharing statements such as "I find it very easy to do anything with. Other than that, I'm completely computer illiterate". The importance of continued ease of use was also noted by current users with focus group participants stating they would be less likely to keep using the mobile application if the vendors made too many changes to the interface. It was clear that ease of use was a big factor in participants' current use of the application and their intention to continue use as highlighted in the following quote: "If it wasn't easy to use I wouldn't be using it anyway". We thus hypothesize:

Hypothesis 1 (H1a). Effort Expectancy (EE) positively influences intentions to adopt the digital platform.

Hypothesis $\mathbf{1}(\mathbf{H 1} \mathbf{b})$. Effort Expectancy (EE) positively influences intentions to continue using the digital platform. 
In terms of Performance Expectancy (PE), in the non-user focus group, participants discussed many potential benefits of the mobile application. The importance of communicating usefulness to increase adoption was evident. For example, one beef farmer stated that he knew the mobile application worked for dairy farmers, but he would need to know "what makes it relevant to my style of farming [...] why I would use it". Participants in the user group highlighted many uses of the digital platform. These uses included alerts when errors were made, easily registering calves, noting sprays, and keeping track of movements. They also noted the usefulness of the continued updates to the digital platform. The link between performance expectancy and continuance intention was apparent with respondents making assertions such as "It's one of them things that you're going to renew every year". We hypothesize:

Hypothesis 2 (H2a). Performance Expectancy (PE) positively influences intentions to adopt the digital platform.

Hypothesis $\mathbf{2}$ (H2b). Performance Expectancy (PE) positively influences intentions to continue using the digital platform.

The role of social influence has received mixed support in the technology adoption literature. However, in the farming context, new innovations must be accepted by the wider farming community prior to adoption [3]. Indeed, this view was repeatedly raised in both focus groups with participants highlighting the importance of peer recommendations. Among the non-user group, participants stated they would be strongly influenced by assertions like "I would use it if another farmer recommended it". These statements highlight the clear link between social influence and adoption decisions but there were also suggestions among the user group that social influence was important in influencing their decision to continue use as highlighted in the following quote: "I started using it because a friend of mine had it [...] I didn't give it a chance initially, but he promised me it was beneficial, so I kept using it". Thus, we hypothesize:

Hypothesis 3 (H3a). Social Influence (SI) positively influences intentions to adopt the digital platform.

Hypothesis $\mathbf{3}$ (H3b). Social Influence (SI) positively influences intentions to continue using the digital platform.

Many respondents discussed the importance of trust in the technology provider as imperative for adopting and continuing to use a digital platform. Among the non-user group, trust was an important factor to overcoming "fear of giving too much information out" with numerous participants stressing the importance of trust. They stated they would need to know and trust the technology provider before "giving it a go". The role of trust also arose in the discussion with current users. Participants in this group noted that the availability of support lines and the visibility of the provider "eased any worries they had". Various aspects of trust were important including competence to protect information and the benevolence and integrity of the platform vendor. The link between trust in the technology provider and intention to continue use was clear among current users with some stating that the assistance they got when they started using the digital platform encouraged them to continue to use it. This is illustrated in the following quote "when you call them, they are brilliant because I was slow enough to get going the first few times. They didn't mind. It was never a hassle. I always feel like I can call if I have an issue". Therefore, we hypothesize:

Hypothesis 4 (H4a). Trust in the technology provider positively influences intentions to adopt the digital platform.

Hypothesis $4 \mathbf{( H 4 b ) . ~ T r u s t ~ i n ~ t h e ~ t e c h n o l o g y ~ p r o v i d e r ~ p o s i t i v e l y ~ i n f l u e n c e s ~ i n t e n t i o n s ~ t o ~ c o n t i n u e ~}$ using the digital platform. 


\subsection{Negative Perceptions}

In terms of negative perceptions, costs of use and work impediment can have a negative influence on continuance intentions [21]. Costs of use of a system relate to individuals' perceptions of unfavorable consequences associated with using a new system [21]. We explored perceptions of costs of use in both focus groups. Among current users, perceived costs of using the mobile application were very low with participants discussing positive consequences as opposed to the negative consequences discussed by Recker [21]. For instance, they felt the mobile application was cost effective and efficient. Thus, we did not include costs of use in the survey for the user group. In contrast, for non-users, the current method of data collection is largely manual and often requires farmers to hire external assistance. Farmers discussed the costs associated with these methods and the burden and stresses. For instance, one farmer noted "I was in an advisor's office to prepare for an audit, it's a few hundred euro for 18 months that's all it does. I think the app is good value if you compare". The time associated with manually tracking was also noted "it would take a few days and nights to get through all the paperwork". Thus, we hypothesize that costs of current methods, even methods which are not related to technology, will positively influence intentions to adopt a technology solution.

Hypothesis 5 (H5). Higher costs of use of current methods positively influence intentions to adopt the mobile application.

Perceived work impediment relates to individuals' perceptions of whether use of the system impedes their work routine; if individuals believe that using a system represents an impediment to their work, they are less likely to continue use [21]. For those not using the digital platform, all data is tracked manually using a method known as "the blue book." The impediments to work caused by this approach was discussed by both users and non-users. Participants in the non-user group discussed the many issues that manual tracking causes such as "trying to remember all the movements and medicines", difficulties in catching errors, and a lengthy process to ensure all data was in place prior to inspections. For users, the digital platform solved many of these issues with participants noting the benefit of the mobile and real-time nature of the digital platform and the pressure it relieves, noting "you don't have all that documentation and you're not trying to remember everything, the mobile application does it all". In line with continuance literature [21], it can be argued that impediments represented by the digital platform will negatively impact intentions to continue use. Thus, we propose:

Hypothesis 6 (H6a). Work impediment positively influences intentions to adopt the digital platform.

Hypothesis $\mathbf{6}(\mathbf{H} \mathbf{6 b})$. Work impediment negatively influence intentions to continue using the digital platform.

A summary of our research model is presented in Figure 1.

\subsection{Mediating Variables}

In addition to the above hypotheses, a number of indirect effects were proposed in line with existing literature and the points stressed most by participants in the focus groups. Given that Effort Expectancy (EE) and Performance Expectancy (PE) are viewed as the primary predictors in TAM and UTAUT, we hypothesize that among the user group, both variables may act as mediators. In the user focus group, conversations around EE and PE were linked not only to participants' reasoning for continuing to use the mobile application but also to discussions around other variables such as trust. We propose that the PE of the technology will mediate positive beliefs, including social influence and trust beliefs. These potential links are evidenced in the following quotes "I will value input from my friends, but I need to be seeing the uses for myself" and "the support from the company is 
important for me to continue to get value from the new features". We also propose that EE will mediate negative beliefs, namely work impediment as the potential impediment the digital platform causes is likely to be influenced by individuals' perceptions of the effort required to use the technology. Social Influence (SI) was highlighted among non-users as core to their adoption decision-making process. Peer recommendations were linked to discussions around deciding whether or not to adopt as well as perceptions of whether the mobile digital platform would be useful in meeting compliance requirements and if their peers felt it was easy to use. In terms of PE, the link between SI and intention to adopt was clear in the following quote: "If my friend has it and says it's helpful, then I'm going to try $i t^{\prime \prime}$. Similar support was shown for the potentially mediating influence of SI on EE in the following quote, "I want to know if he's using it and finding it easy to use before I give it a go". Therefore, we propose that social influence will mediate positive beliefs, such as PE and EE among non-users.

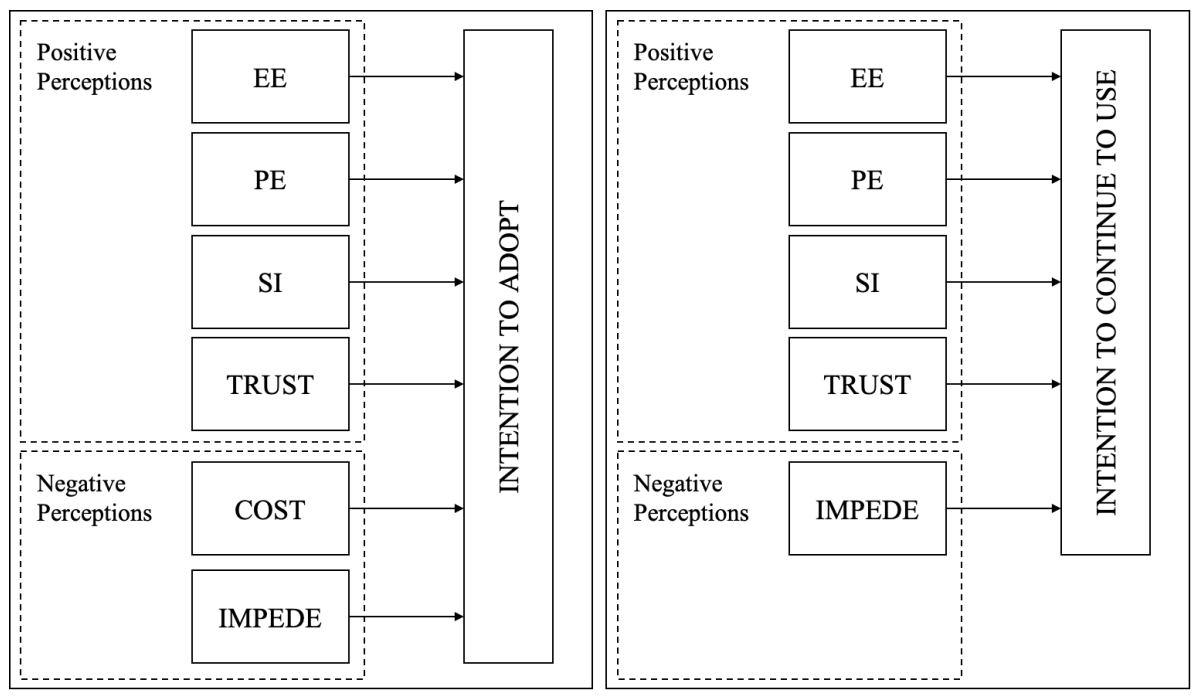

Figure 1. Proposed research models for non-Users and users.

\section{Survey Development and Sampling}

The surveys were developed by adapting validated constructs to suit the context of both samples. Adoption and continuance intentions, EE, SI, and PE were all measured with three items based on Venkatesh et al. [14]; trust beliefs were measured with four items based on Hong and Thong [32]; and costs of use and work impediment were measured with three and four items, respectively based on Recker [21]. Control variables included gender, age, education, farm size, and technology experience. The two surveys were pilot tested among academic experts and members of the farming community. The survey instructions were subsequently refined prior to distribution. All survey items are listed in Appendix A.3. As all variables were measured at the same point in time, concerns may be raised for Common Method Bias (CMB). To mitigate against such biases, a number of procedural remedies were applied in the survey design as per MacKenzie et al. [33]. These included ensuring all items were unambiguous, notifying participants that there were no right or wrong answers, varying scale anchors, and ensuring descriptions of the digital platform were clear and neutrally worded. Endogenous variables, namely intentions to adopt or continue use, were also measured prior to exogenous variables to ensure these variables did not positively or negatively prime responses. The order of exogenous variables was randomized to ensure the varied presentation of positively framed variables, such as perceived usefulness and negatively framed variables, such as work impediment.

Both samples were drawn from members of the family-operated farming community in Ireland. For the user survey, an email invitation was sent to current users of the mobile digital platform, for whom valid email addresses were available. For the non-user survey, an email invitation was sent to members of the farming community who had previously 
expressed interest in the mobile application but had not yet adopted. This ensured all nonusers had some awareness of the mobile application and its offering. For the user group, 553 complete and usable responses were received. For the non-user group, 191 complete and usable responses were received. Given the population size outlined in Section 3, a sample of 744 responses provides a $3.59 \%$ confidence interval. The majority of respondents were male ( $89 \%$ of users; $84 \%$ of non-users). This is representative of national trends where $88 \%$ of farm holders being male [31]. It is interesting to note the age distribution of respondents, with the majority falling between 25 and 64 in both groups. In terms of farm size, the second largest group of respondents (33\% in the user group, 31\% in the non-user group) stated their farm was 31-50 hectares, close to the national average of 32.5 hectares [31]. Respondents in the user group were asked how long they have been using the digital platform. Approximately $66 \%$ had been using the mobile application for more than one year, a further $30 \%$ had been using it between $4-11$ months, with the remaining using the mobile application for less than 3 months. The sample characteristics are outlined in Table 1.

Table 1. Sample characteristics for both groups.

\begin{tabular}{|c|c|c|c|c|c|}
\hline \multirow{2}{*}{ Variable } & \multirow{2}{*}{ Category } & \multicolumn{2}{|c|}{ Non-Users } & \multicolumn{2}{|c|}{ Users } \\
\hline & & $\mathbf{N}$ & $\%$ & $\mathbf{N}$ & $\%$ \\
\hline \multirow{2}{*}{ Gender } & Female & 31 & $16.20 \%$ & 60 & $10.80 \%$ \\
\hline & Male & 160 & $83.80 \%$ & 493 & $89.20 \%$ \\
\hline \multirow{6}{*}{ Age } & 18 to 24 & 21 & $11.00 \%$ & 24 & $4.30 \%$ \\
\hline & 25 to 34 & 33 & $17.30 \%$ & 100 & $18.10 \%$ \\
\hline & 35 to 44 & 46 & $24.10 \%$ & 196 & $35.40 \%$ \\
\hline & 45 to 54 & 58 & $30.40 \%$ & 155 & $28.00 \%$ \\
\hline & 55 to 64 & 29 & $15.20 \%$ & 67 & $12.10 \%$ \\
\hline & 65 to 74 & 4 & $2.10 \%$ & 11 & $2.00 \%$ \\
\hline \multirow{5}{*}{$\begin{array}{l}\text { Farm Type (respondents } \\
\text { could choose multiple } \\
\text { categories) }\end{array}$} & Dairy cows & 68 & $35.60 \%$ & 256 & $46.30 \%$ \\
\hline & Suckler cows & 72 & $37.70 \%$ & 230 & $41.60 \%$ \\
\hline & Beef & 57 & $29.80 \%$ & 215 & $38.90 \%$ \\
\hline & Sheep & 31 & $16.20 \%$ & 88 & $15.90 \%$ \\
\hline & Tillage & 12 & $6.30 \%$ & 24 & $4.30 \%$ \\
\hline \multirow{7}{*}{ Farm Size } & 5 Hectares or less & 1 & $0.50 \%$ & 1 & $0.20 \%$ \\
\hline & 6- 10 Hectares & 4 & $2.10 \%$ & 8 & $1.40 \%$ \\
\hline & 11-20 Hectares & 16 & $8.40 \%$ & 37 & $6.70 \%$ \\
\hline & 21-30 Hectares & 25 & $13.10 \%$ & 78 & $14.10 \%$ \\
\hline & 31-50 Hectares & 50 & $30.90 \%$ & 181 & $32.70 \%$ \\
\hline & 51-100 Hectares & 63 & $33.00 \%$ & 192 & $34.70 \%$ \\
\hline & Over 100 Hectares & 23 & $12.00 \%$ & 56 & $10.10 \%$ \\
\hline
\end{tabular}

\section{Quantitative Data Analysis and Findings}

All data were screened to ensure the assumptions required for multivariate analysis were met. The two datasets were screened and analyzed separately. Both data sets met normality, linearity, homoscedasticity, and multicollinearity requirements [34]. The proposed models and hypotheses were tested using Partial Least Square regression.

The first step of analysis involved assessing the model fit for both samples by calculating the Standardized Root Mean square Residual (SRMR) as per Henseler et al. [35]. Both 
samples indicated good fit with SRMR scores below 0.08 (user group $=0.026$, non-user group $=0.044$ ). The next step of analysis involved testing the validity and reliability of all constructs. First, convergent validity was tested by calculating the Average Variance Extracted (AVE). As the AVE for each construct was above 0.50, the distinct nature of each construct is apparent [36]. Second, discriminant validity was tested by comparing the square root of the AVE and the correlation between each set of constructs [34]. All variables demonstrated sufficient discriminant validity, as the square root of the AVE for each construct was greater than intercorrelation values. Discriminant validity was further demonstrated as all constructs had a heterotrait-monotrait ratio of correlations scores significantly below 1 [35]. Thirdly, reliability was tested by calculating Composite Reliability (CR). The CR for all constructs was above the recommended 0.70 value [37]. The data for both samples was therefore deemed valid and reliable as shown in Table 2.

Table 2. Composite Reliability (CR) and Average Variance Extracted (AVE) scores.

\begin{tabular}{lcccc}
\hline & \multicolumn{2}{c}{ Non-User } & \multicolumn{2}{c}{ Users } \\
\hline Variable & CR & AVE & CR & AVE \\
\hline PE & 0.902 & 0.757 & 0.931 & 0.820 \\
\hline EE & 0.914 & 0.757 & 0.943 & 0.847 \\
\hline INTENTION & 0.954 & 0.872 & 0.955 & 0.876 \\
\hline TRUST & 0.883 & 0.653 & 0.881 & 0.654 \\
\hline IMPEDE & 0.927 & 0.760 & 0.919 & 0.695 \\
\hline COSTS & 0.801 & 0.597 & $\mathrm{~N} / \mathrm{A}$ & $\mathrm{N} / \mathrm{A}$ \\
\hline SI & 0.859 & 0.676 & 0.887 & 0.727 \\
\hline
\end{tabular}

The final step of data analysis involved testing the structural models outlined in Figure 1 and exploring the proposed direct and indirect effects. For the non-user group, EE and PE both had a positive influence on intentions to adopt, but neither relationship was significant thereby rejecting $\mathrm{H} 1 \mathrm{a}$ and $\mathrm{H} 2 \mathrm{a}$. A similar relationship was evidenced between trust beliefs and adoption intention, thereby rejecting H4a. Social influence had a positive and significant influence on intention to adopt the digital platform $(\beta=0.332, p<0.01)$, offering strong support for H3a. In terms of negative perceptions, neither costs of current method or perceived impediment of current method significantly influenced adoption intentions. In summary, only social influence had a significant and direct influence on adoption intention.

Among the user group, effort expectancy had a significant and positive influence on intentions to continue to use the digital platform $(\beta=0.159, p<0.01)$, supporting H1b. Performance expectancy also had a significant and positive influence $(\beta=0.485$, $p<0.01$ ) supporting H2b. Neither social influence nor trust beliefs significantly influenced continuance intention, thus causing us to reject $\mathrm{H} 3 \mathrm{~b}$ and H4b. Perceived work impediment associated with the mobile application did have a negative influence on intention to continue use but this relationship was insignificant. In summary, only PE and EE had significant and direct influences on individuals' intentions to continue use, with PE representing the strongest predictor as is the case in the UTAUT model. The findings from the direct relationships are outlined in Table 3. 
Table 3. Direct relationships.

\begin{tabular}{|c|c|}
\hline \multicolumn{2}{|l|}{ Non-Users } \\
\hline Hypothesis & Finding \\
\hline H1a. EE positively influences adoption intention. & (0.148) n.s. \\
\hline H2a. PE positively influences adoption intention. & $(0.182)$ n.s. \\
\hline H3a. Social influence positively influences adoption intention. & $(0.332)^{* *}$ \\
\hline H4a. Trust beliefs positively influences adoption intention. & (0.120) n.s. \\
\hline H5a. Costs of use positively influences adoption intention. & $(-0.004)$ n.s. \\
\hline H6a. Work impediment positively influences adoption intention. & (0.176) n.s. \\
\hline \multicolumn{2}{|l|}{ Users } \\
\hline Hypothesis & Finding \\
\hline H1b. EE positively influences continuance intention. & $(0.159)^{* *}$ \\
\hline H2b. PE positively influences continuance intention. & $(0.485)^{* *}$ \\
\hline H3b. Social influence positively influences continuance intention. & (0.067) n.s. \\
\hline H4b. Trust beliefs positively influences continuance intention. & $(0.032)$ n.s \\
\hline $\mathrm{N} / \mathrm{A}$ & \\
\hline
\end{tabular}

H6b. Work impediment negatively influences continuance intention. $\quad(-0.090)$ n.s. Note: ${ }^{* *}$ denotes significance at the $5 \%$ levels. n.s. = not significant.

Bootstrapping with 1000 samples was utilized to explore indirect effects. Strong support for the proposed mediation effects were found as outlined in Table 4. Among the non-user group, social influence fully mediated the influence of performance expectancy on adoption intention with PE having a significant indirect effect on intention ( $\beta=0.133$, $p<0.01)$. Effort expectancy also had a significant and positive indirect influence on adoption intention via social influence $(\beta=0.144, p<0.01)$. The mediated model explained $51 \%$ of variance in intention to adopt the digital platform. In the user model, performance expectancy fully mediated trust beliefs and social influence as proposed. Trust beliefs had a significant indirect influence on intention to continue use $(\beta=0.094, p<0.01)$, as did social influence $(\beta=0.093, p<0.05)$. Perceived impediment had a significant and negative indirect influence on continuance intention via effort expectancy $(\beta=-0.198, p<0.01)$, offering strong support for full mediation. For the user sample, the proposed model explained $51.6 \%$ of variance in continuance intention.

Table 4. Mediation relationships.

\begin{tabular}{|c|c|}
\hline \multicolumn{2}{|l|}{ Non-Users } \\
\hline Hypothesis & Finding \\
\hline H7a. SI mediates the influence of PE on adoption intention. & $(0.133)^{* *} \quad$ Full mediation \\
\hline H8a. SI mediates the influence of EE on adoption intention. & Full mediation \\
\hline \multicolumn{2}{|l|}{ Users } \\
\hline Hypothesis & Finding \\
\hline H7b. PE mediates the influence of trust beliefs on intention. & $(0.094) * * \quad$ Full mediation \\
\hline H8b. PE mediates the influence of SI on intention. & Full mediation \\
\hline H9b. EE mediates the influence of impediment on intention. & $(-0.198) * *$ Full mediation \\
\hline
\end{tabular}




\section{Discussion}

This study employed a sequential mixed-methods approach to explore initial adoption and subsequent use behaviors by farmers of a mobile digital platform. Two focus groups were conducted with users and non-users of the mobile farm management digital platform to develop models for understanding the factors driving farmers' initial adoption and continuance intentions. These models were empirically tested using surveys and performed well, explaining $51 \%$ and $51.6 \%$ of variance in adoption and continuance intentions by non-users and users, respectively. Following the surveys, the research models were revised to illustrate the empirically supported relationships, as shown in Figure 2a,b.

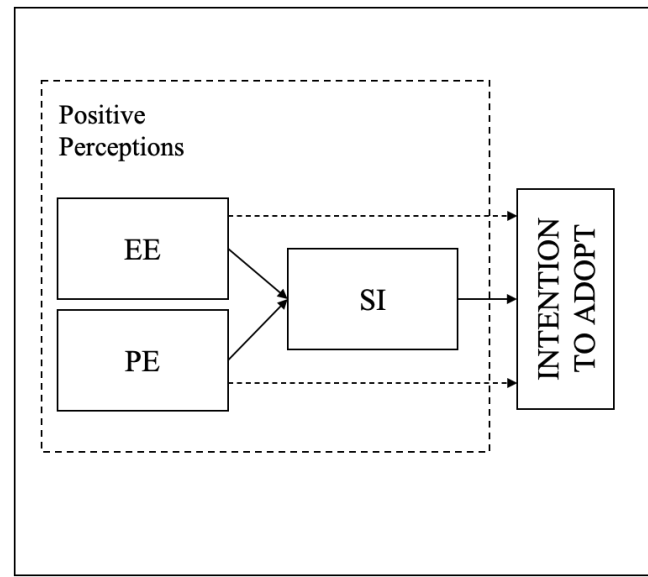

(a)

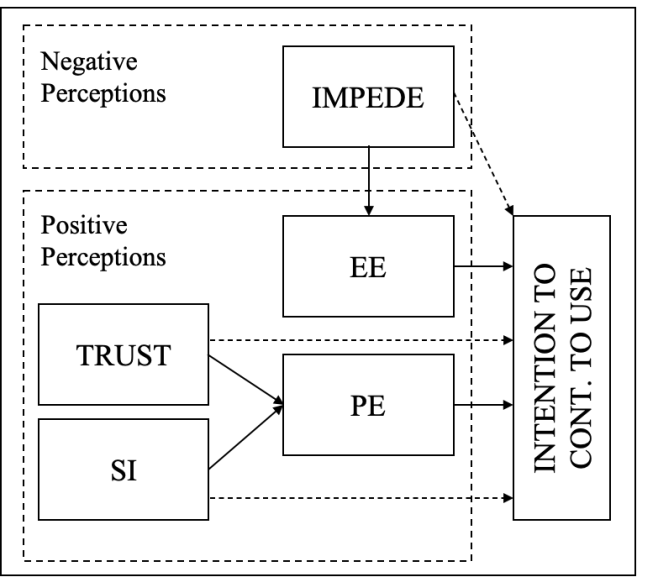

(b)

Figure 2. (a) Predictors of adoption, (b) Predictors of continuance. Note: solid arrow = direct relationship; dotted arrow $=$ indirect relationship.

Among non-users, the strongest predictor of adoption is social influence, specifically individuals' perceptions of their peers' attitudes toward adopting the technology [14]. Social influence also fully mediates the influence of performance expectancy and effort expectancy on adoption by non-users. This is interesting as performance expectancy and effort expectancy are typically the strongest influencers on initial adoption decisions in many other contexts $[13,14]$. This study provides substantial empirical support for the importance of peer recommendations in the context of family-operated farms [3]. Indeed, the combined qualitative and quantitative findings suggest that farmers look to their peers for advice prior to making a decision on whether or not to adopt.

Among current users, performance expectancy has the strongest influence on intentions to continue use. Following initial adoption, farmers' actual experience with using the mobile application becomes the dominant influence on continued use. This is not surprising as farmers must believe that the mobile application is beneficial for them to continue to use it. Effort expectancy also positively impacts intentions to continue to use the application. This again represents an important attribute of the sample and this context. Even farmers using the digital platform described themselves as lacking technical skills with some noting that they use the mobile application primarily because it was so easy to learn. In addition, performance expectancy fully mediates the influence of social influence and trust beliefs on continuance intention. The indirect influence of peer recommendations was alluded to in the focus groups. Farmers noted that they would continue to ask their friends how useful they found the mobile application, and would be further influenced if they found the digital platform helpful in improving their data processing and farm management. Trust beliefs regarding the technology and the vendor strengthened individuals' perception of the usefulness of the technology, indirectly influencing continuance intentions. Effort expectancy fully mediates the influence of work impediment on continuance intention. This indicates that even if respondents believe the digital platform impedes their farm 
work on some level, provided the digital platform is easy to use, they will continue to use it.

\section{Contributions to Theory and Practice}

This study makes several contributions to the literature and to practice. Firstly, the study addresses two important gaps in the literature by (1) examining the positive and negative factors driving mobile technology adoption in the important but under-examined agricultural context, and (2) adding to the emerging but nascent literature on the positive and negative factors impacting post-adoption use behaviors. The study extends technology adoption theory beyond an emphasis purely on positive predictors to develop, test, and refine a model for understanding farmers' intentions to adopt a mobile application for farm management. The findings provide support for the continued relevance of technology acceptance models for understanding adoption intentions, specifically the role of PE, EE, and social influence, all of which are represented in some form in the UTAUT model. Interestingly in this context, social influence is the strongest predictor, mediating the influence of PE and EE. The study also adds to the small but emerging body of continuance intention literature, most specifically in the context of farmers' mobile technology adoption. Among users of the mobile application, an extended UTAUT model is supported. PE remains the strongest predictor of continuance intention with the study highlighting the importance of perceptions of usefulness after adoption. Indeed, in this context, farmers noted they would continue use for as long as the digital platform assisted them in managing their data and compliance requirements. In both focus groups, participants discussed their use of technology for personal purposes and their perceived proficiency. From these discussions, it became apparent that farmers continue to resist adopting digital technologies and are not extremely confident in their own technical abilities. Thus, an easy-to-use digital platform is fundamental to sustained usage.

Secondly, the study makes a number of empirical contributions by finding empirical support for salient direct and indirect relationships. This includes support for two mediating UTAUT models that position social influence as a mediator for adoption, and include trust beliefs and negative perceptions (work impediment) for continuance behaviors. Thirdly, the insights from the study provide actionable practical insights for increasing adoption of the technology and sustained usage. The importance of social influence among non-users illustrates the potential power of peer recommendations. As a result, technology providers should consider incentivizing the recommendations of current users in a bid to increase adoption by those in their social network. Peer recommendations should focus on ease of use and the usefulness of the various features. In addition, the focus groups highlighted the importance of clear operational benefits from using the digital platform and ease of use. These operational benefits, the easy-to-learn (and stable) interface, and readily available user support should be highlighted to non-users and current users. Due to low technical proficiency among the farming community, the user support offered by the platform provider to assist users is extremely valuable and should be highlighted to prospective users prior to sign up and routinely reinforced by assisting them with learning the many features of the mobile application during continued use. For example, farmers will be subject to an inspection every 18 months. The timing of this inspection will vary for farmers and assistance in preparing reports for their first audit using the digital platform could be imperative in ensuring farmers realize benefit from the application and continue use as a result.

\section{Limitations and Conclusions}

As with any research study, the limitations of this work should be noted. First, the study focuses on the adoption of a single mobile digital platform for farm management. This was necessitated by the aim of the research to understand the factors impacting adoption and continuance intention. Future research could explore technology adoption among this group in broader terms. Secondly, the study sample was drawn from current 
customers using this mobile digital platform and farmers who have previously expressed interest but have not yet adopted. This may exclude farmers with little awareness of the digital platform or have no technology experience. Future research could explore the barriers to adoption among farmers who currently resist adopting any technology for social or business purposes. Furthermore, additional cohort analysis may provide additional insights, including prior experience and adoption of agricultural technologies. We contend that further research into the adoption and usage behaviors of the family-operated farming community represents a fruitful and interesting avenue for research, especially with the growing interest in locally sourced, high quality, and traceable food.

In closing, digital platforms, such as a mobile application for farm management, present many performance-enhancing opportunities for the farming community that include reduced paper work, streamlined compliance requirements, improved productivity, and automated data backups. However, many family-operated farming enterprises continue to resist the adoption of these technologies. This study extended the UTAUT model to the new context of family-operated farming enterprises to understand both the drivers of initial adoption intention and continued use intention. The study highlights the importance of social influence, perceived usefulness, and perceived ease of use for increasing adoption and sustaining the usage of digital technology among the family-operated farming community.

Author Contributions: Conceptualization, T.L.; methodology, G.F. and P.R.; validation, J.M. and T.L.; formal analysis, G.F.; data curation, G.F., P.R. and T.L.; writing—original draft preparation, G.F., J.M., P.R. and T.L.; writing-review and editing, G.F., J.M., P.R. and T.L. All authors have read and agreed to the published version of the manuscript.

Funding: This research was partly supported by the Irish Centre for Cloud Computing and Commerce, an Irish National Technology Centre funded by Enterprise Ireland, and the Irish Industrial Development Authority.

Institutional Review Board Statement: The study was conducted according to the research ethics guidelines of Dublin City University and approved by DCU's Research Ethics Committee.

Informed Consent Statement: Informed consent was obtained from all subjects involved in the study.

Data Availability Statement: The data are available upon reasonable request by correspondence with the author.

Conflicts of Interest: The authors declare no conflict of interest.

\section{Abbreviations}

The following abbreviations are used in this manuscript:

$\begin{array}{ll}\text { AVE } & \text { Average Variance Extracted } \\ \text { CMB } & \text { Common Method Bias } \\ \text { CR } & \text { Composite Reliability } \\ \text { EE } & \text { Effort Expectancy } \\ \text { IT } & \text { Information Technology } \\ \text { PE } & \text { Performance Expectancy } \\ \text { PEOU } & \text { Perceived Ease of Use } \\ \text { PU } & \text { Perceived Usefulness } \\ \text { SI } & \text { Social Influence } \\ \text { SRMR } & \text { Standardized Root Mean square Residual } \\ \text { TAM } & \text { Technology Acceptance Model } \\ \text { TPB } & \text { Theory of Planned Behavior } \\ \text { TRA } & \text { Theory of Reasoned Action } \\ \text { UTAUT } & \text { Unified Theory of Acceptance and Use of Technology }\end{array}$




\section{Appendix A}

Appendix A.1. Focus Groups Topic Guides

Table A1. Topic guide: User focus group.

\begin{tabular}{|c|c|c|c|}
\hline Construct & Source & Questions & Theme/Sub-Theme \\
\hline $\begin{array}{l}\text { Performance Expectancy/ } \\
\text { Perceived Usefulness }\end{array}$ & $\begin{array}{l}\text { UTAUT [14] } \\
\text { TAM [17] }\end{array}$ & $\begin{array}{l}\text { How useful have you found the application in } \\
\text { helping you to collect data for the farm? } \\
\text { [Prompts: Did the application match your } \\
\text { expectations? Any features missing or extra } \\
\text { features? How important are these features to } \\
\text { your farm management? Has the application } \\
\text { changed your processes and activities, if so } \\
\text { how?] }\end{array}$ & $\begin{array}{l}\text { Perceived Usefulness } \\
\text { Link to initial adoption decision } \\
\text { Link to continuance intention }\end{array}$ \\
\hline $\begin{array}{l}\text { Effort Expectancy/ } \\
\text { Perceived Ease of Use }\end{array}$ & $\begin{array}{l}\text { UTAUT [14] } \\
\text { TAM [17] }\end{array}$ & $\begin{array}{l}\text { How easy do you find the application to use? } \\
\text { How difficult was it to use the application } \\
\text { initially? } \\
\text { [Prompts: Is the application as easy to use as } \\
\text { you expected? Could it be easier to use? How } \\
\text { important is ease of use to you?] }\end{array}$ & $\begin{array}{l}\text { Perception of ease of use } \\
\text { Link to initial adoption decision } \\
\text { Link to continuance intention }\end{array}$ \\
\hline $\begin{array}{l}\text { Social Influence/ } \\
\text { Subjective Norm }\end{array}$ & $\begin{array}{l}\text { UTAUT [14] } \\
\text { TPB [15] }\end{array}$ & $\begin{array}{l}\text { Where did you first hear of the application? } \\
\text { Did any of your friends or fellow farmers } \\
\text { recommend the application? }\end{array}$ & Social influence prior to adoption \\
\hline Trust Beliefs & {$[32]$} & $\begin{array}{l}\text { How would you describe your trust in the } \\
\text { application? } \\
\text { Is trust an important factor in your decision to } \\
\text { continue to use the application? } \\
\text { Was trust important in your initial decision to } \\
\text { try the application? }\end{array}$ & $\begin{array}{l}\text { Trust beliefs } \\
\text { Link to initial adoption decision } \\
\text { Link to continuance intention }\end{array}$ \\
\hline $\begin{array}{l}\text { Perceived Impediment } \\
\text { of Application }\end{array}$ & [21] & $\begin{array}{l}\text { Does the application have negative effects on } \\
\text { your ability to do your work? }\end{array}$ & $\begin{array}{l}\text { Perceived impediment associated } \\
\text { with the application }\end{array}$ \\
\hline Cost & {$[21]$} & $\begin{array}{l}\text { [Prompts: Was cost an important factor in } \\
\text { influencing your decision to try the application } \\
\text { initially? Does the cost associated with the } \\
\text { application influence your } \\
\text { decision to use it in the future? }\end{array}$ & $\begin{array}{l}\text { Costs associated with the application } \\
\text { Link to initial adoption decision } \\
\text { Link to continuance intention }\end{array}$ \\
\hline
\end{tabular}


Table A2. Topic guide: Non-user focus group.

\begin{tabular}{|c|c|c|c|}
\hline Construct & Source & Questions & Theme/Sub-Theme \\
\hline $\begin{array}{l}\text { Performance Expectancy/ } \\
\text { Perceived usefulness }\end{array}$ & $\begin{array}{l}\text { UTAUT [14] } \\
\text { TAM [17] }\end{array}$ & $\begin{array}{l}\text { Based on this description/your current } \\
\text { knowledge do you think the application } \\
\text { would be useful in helping you manage the } \\
\text { farm? } \\
\text { [Prompts: What features do you think would } \\
\text { be useful? How important are these features } \\
\text { to you? Any features missing or extra features? } \\
\text { Would these features influence your willingness } \\
\text { to try the application? }\end{array}$ & $\begin{array}{l}\text { Perceived Usefulness } \\
\text { Link to willingness to adopt }\end{array}$ \\
\hline $\begin{array}{l}\text { Effort Expectancy/ } \\
\text { Perceived Ease of Use }\end{array}$ & $\begin{array}{l}\text { UTAUT [14] } \\
\text { TAM [17] }\end{array}$ & $\begin{array}{l}\text { How easy do you think the application would be } \\
\text { to use? } \\
\text { [Prompts: How important is ease of use to you? } \\
\text { Would this influence your willingness to try the } \\
\text { application?] }\end{array}$ & $\begin{array}{l}\text { Perception of ease of use } \\
\text { Link to willingness to adopt }\end{array}$ \\
\hline $\begin{array}{l}\text { Social Influence/ } \\
\text { Subjective Norm }\end{array}$ & $\begin{array}{l}\text { UTAUT [14] } \\
\text { TPB [15] }\end{array}$ & $\begin{array}{l}\text { Where did you first hear of the application? } \\
\text { Have any of your friends or fellow farmers } \\
\text { recommended the application? Would a } \\
\text { recommendation from a fellow farmer or } \\
\text { friend influence your willingness to try the } \\
\text { application? }\end{array}$ & Social influence and adoption \\
\hline Trust Beliefs & [32] & $\begin{array}{l}\text { Based on what you know so far, how would } \\
\text { you describe your trust in the application and } \\
\text { the company? Is trust an important factor in } \\
\text { your decision to try the application? }\end{array}$ & $\begin{array}{l}\text { Trust beliefs } \\
\text { Link to adoption decision }\end{array}$ \\
\hline $\begin{array}{l}\text { Perceived Impediment } \\
\text { of Application }\end{array}$ & [21] & $\begin{array}{l}\text { How do you currently track data on the farm? } \\
\text { Does this approach have any negative effects } \\
\text { on your work? Would you try the application if } \\
\text { you believed it could overcome these issues? }\end{array}$ & $\begin{array}{l}\text { Perceived impediment associated } \\
\text { with current methods } \\
\text { Link to intention to adopt new } \\
\text { methods }\end{array}$ \\
\hline Cost & [21] & $\begin{array}{l}\text { What are the costs associated with your current } \\
\text { methods? Would you try the application if it } \\
\text { alleviated some of these costs? }\end{array}$ & $\begin{array}{l}\text { Costs associated with current methods } \\
\text { Link to intention to adopt new } \\
\text { methods }\end{array}$ \\
\hline
\end{tabular}

\section{Appendix A.2. Example Quotes and Associated Hypotheses}

Table A3. User focus group.

\begin{tabular}{|c|c|c|}
\hline Construct & Example Quote & Hypothesis \\
\hline Effort Expectancy & $\begin{array}{l}\text { "In my experience, it's very easy to do on } \\
\text { the app. It makes compliance easier and } \\
\text { quicker so I plan to continue using it". }\end{array}$ & $\begin{array}{l}\text { Effort expectancy positively } \\
\text { influences intention to continue } \\
\text { use of the application. }\end{array}$ \\
\hline $\begin{array}{l}\text { Performance } \\
\text { Expectancy }\end{array}$ & $\begin{array}{l}\text { "Yeah once you're familiar and happy with } \\
\text { it, I don't see why you would change and } \\
\text { it does keep developing further so why } \\
\text { wouldn't I keep using it?". }\end{array}$ & $\begin{array}{l}\text { Performance expectancy } \\
\text { positively influences intention } \\
\text { to continue use of the application. }\end{array}$ \\
\hline Social Influence & $\begin{array}{l}\text { "If your friend has something, you ask him } \\
\text { how you getting on with it... oh I think it's } \\
\text { great, it makes you think it must be good } \\
\text { and you will want to try it. It's the same } \\
\text { once you have it, you ask your friends } \\
\text { what features they're using and how they } \\
\text { are finding it and that might change how } \\
\text { you view it. Or if my friend isn't getting } \\
\text { much use out of it, I might tell him how } \\
\text { easy it has made movements for me and } \\
\text { he might try that next time." }\end{array}$ & $\begin{array}{l}\text { Social influence will influence } \\
\text { intention to continue use of the } \\
\text { application. }\end{array}$ \\
\hline
\end{tabular}


Table A3. Cont.

\begin{tabular}{lll}
\hline Construct & \multicolumn{1}{c}{ Example Quote } & \multicolumn{1}{c}{ Hypothesis } \\
\hline Trust beliefs & $\begin{array}{l}\text { "They don't just sell it to you and that's it. } \\
\text { There are normal people behind the app, } \\
\text { they're always available and willing to } \\
\text { help". }\end{array}$ & $\begin{array}{l}\text { Trust beliefs will positively } \\
\text { influence intention to continue } \\
\text { use of the application. }\end{array}$ \\
$\begin{array}{ll}\text { Perceived impediment } \\
\text { of current method }\end{array}$ & $\begin{array}{l}\text { Perceived impediment of the } \\
\text { application will negatively } \\
\text { influence intention to continue } \\
\text { use of the application. }\end{array}$ \\
\hline
\end{tabular}

Table A4. Non-user focus group.

\begin{tabular}{lll}
\hline \multicolumn{1}{c}{ Construct } & \multicolumn{1}{c}{ Example Quote } & \multicolumn{1}{c}{ Hypothesis } \\
\hline Effort Expectancy & $\begin{array}{l}\text { "I think that's a reason a lot of people don't have it, } \\
\text { when they hear about technology, they tune out they } \\
\text { don't want to know. They don't realise how easy it is. } \\
\text { Especially in the older generation. But it seems so } \\
\text { easy to use, I think most people could use that". }\end{array}$ & $\begin{array}{l}\text { Effort expectancy will positively } \\
\text { influence intentions to adopt the } \\
\text { application. }\end{array}$ \\
\hline $\begin{array}{l}\text { Performance } \\
\text { Expectancy }\end{array}$ & $\begin{array}{l}\text { "It seems you can go into as much detail as possible } \\
\text { and do everything you need. It could definitely } \\
\text { make the job more efficient". }\end{array}$ & $\begin{array}{l}\text { Performance expectancy will } \\
\text { positively influence intentions to } \\
\text { adopt the application. }\end{array}$ \\
\hline Social Influence & $\begin{array}{l}\text { "If you knew the farmer and they said look this } \\
\text { is a good system and they show it to you, you'd } \\
\text { go home and look it up and maybe try it". }\end{array}$ & $\begin{array}{l}\text { Social influence will positively } \\
\text { influence intentions to adopt the } \\
\text { application. }\end{array}$ \\
\hline Trust Beliefs & $\begin{array}{l}\text { "I need to feel like they are reliable and available } \\
\text { to help me". }\end{array}$ & $\begin{array}{l}\text { Trust beliefs will positively influence } \\
\text { intentions to adopt the application. }\end{array}$ \\
\hline $\begin{array}{l}\text { Impediment of } \\
\text { Current method }\end{array}$ & $\begin{array}{l}\text { "I need to keep track of everything in the book } \\
\text { and it's a nuisance when inspection time rolls } \\
\text { around". }\end{array}$ & $\begin{array}{l}\text { Impediment of current method will } \\
\text { positively influence intentions to adopt } \\
\text { the application }\end{array}$ \\
\hline Costs of Current & $\begin{array}{l}\text { "If you have to pay an advisor, you're talking } \\
\text { about 600 euro. I think the big thing is stress. If } \\
\text { you're doing all that paperwork for things you } \\
\text { should have done six months ago or 18 months } \\
\text { ago and you're making up stories. If the mobile } \\
\text { application could help, you could prove } \\
\text { everything". }\end{array}$ & $\begin{array}{l}\text { Costs of current method will positively } \\
\text { influence intentions to adopt the } \\
\text { application. }\end{array}$ \\
\hline
\end{tabular}

Appendix A.3. Survey Items

Table A5. Non-user focus group.

\begin{tabular}{cll}
\hline \multicolumn{1}{c}{ Constructs } & \multicolumn{1}{c}{ User Survey } & \multicolumn{1}{c}{ Non-User Survey } \\
\hline & $\begin{array}{l}\text { PE1: I find the application useful for } \\
\text { managing compliance requirements. }\end{array}$ & $\begin{array}{l}\text { PE1: I would find the application useful for } \\
\text { managing compliance requirements. }\end{array}$ \\
\cline { 2 - 3 } $\begin{array}{l}\text { Performance } \\
\text { Expectancy (PE) [14] }\end{array}$ & $\begin{array}{l}\text { PE2: The application helps me complete } \\
\text { compliance requirements more quickly. }\end{array}$ & $\begin{array}{l}\text { PE2: Using the application would help me } \\
\text { complete compliance requirements more } \\
\text { quickly. }\end{array}$ \\
\cline { 2 - 3 } & $\begin{array}{l}\text { PE3: Using the application increases my } \\
\text { productivity in managing compliance } \\
\text { requirements. }\end{array}$ & $\begin{array}{l}\text { PE3: Using the application would increase } \\
\text { my productivity in managing compliance } \\
\text { requirements. }\end{array}$ \\
\hline
\end{tabular}


Table A5. Cont.

\begin{tabular}{|c|c|c|}
\hline Constructs & User Survey & Non-User Survey \\
\hline \multirow{3}{*}{$\begin{array}{l}\text { Effort } \\
\text { Expectancy (EE) [14] }\end{array}$} & $\begin{array}{l}\text { EE1: It has been easy for me to become } \\
\text { skillful at using the application. }\end{array}$ & $\begin{array}{l}\text { EE1: It would be easy for me to become } \\
\text { skillful at using the application. }\end{array}$ \\
\hline & EE2: I find the application easy to use. & EE2: I would find the application easy to use. \\
\hline & $\begin{array}{l}\text { EE3: Learning to use the application has } \\
\text { been easy for me. }\end{array}$ & $\begin{array}{l}\text { EE3: Learning to use the application would be } \\
\text { easy for me. }\end{array}$ \\
\hline \multirow{3}{*}{ Social influence [14] } & $\begin{array}{l}\text { SI1: Members of the farming community } \\
\text { think I should continue to use the } \\
\text { application to track all compliance } \\
\text { information. }\end{array}$ & $\begin{array}{l}\text { SI1: Members of the farming community think } \\
\text { I should use the application to track all } \\
\text { compliance information. }\end{array}$ \\
\hline & $\begin{array}{l}\text { SI2: My family members think I should } \\
\text { continue to use the application to track } \\
\text { all compliance information. }\end{array}$ & $\begin{array}{l}\text { SI2: My family members think I should use the } \\
\text { application to track all compliance information. }\end{array}$ \\
\hline & $\begin{array}{l}\text { SI3: My friends think I should continue } \\
\text { to use the application to track all compliance } \\
\text { information. }\end{array}$ & $\begin{array}{l}\text { SI3: My friends think I should use the application } \\
\text { to track all compliance information. }\end{array}$ \\
\hline \multirow{5}{*}{ Trust beliefs [32] } & $\begin{array}{l}\text { Based on my experience with the application to } \\
\text { date: }\end{array}$ & $\begin{array}{l}\text { Based on my understanding of the application to } \\
\text { date: }\end{array}$ \\
\hline & TRU1: I know they are honest. & TRU1: I know they are honest. \\
\hline & TRU2: I know they care about customers & TRU2: I know they care about customers \\
\hline & TRU3: I know they are not opportunistic & TRU3: I know they are not opportunistic \\
\hline & $\begin{array}{l}\text { TRU4: I know they are competent in providing } \\
\text { their services }\end{array}$ & $\begin{array}{l}\text { TRU4: I know they are competent in providing } \\
\text { their services }\end{array}$ \\
\hline \multirow{5}{*}{$\begin{array}{l}\text { Impediment of application } \\
\text { or existing method [21] }\end{array}$} & he application: & xisting method: \\
\hline & $\begin{array}{l}\text { IMPEDE1: Holds me back from doing my actual } \\
\text { work. }\end{array}$ & $\begin{array}{l}\text { IMPEDE1: Holds me back from doing my actual } \\
\text { work. }\end{array}$ \\
\hline & IMPEDE2: Hinders my productivity at work. & IMPEDE2: Hinders my productivity at work. \\
\hline & IMPEDE3: Impedes my efficiency at work. & IMPEDE3: Impedes my efficiency at work. \\
\hline & $\begin{array}{l}\text { IMPEDE4: Slows down my ability to track } \\
\text { information for compliance }\end{array}$ & $\begin{array}{l}\text { IMPEDE4: Slows down my ability to track } \\
\text { information for compliance }\end{array}$ \\
\hline \multirow{4}{*}{$\begin{array}{l}\text { Cost of current } \\
\text { method [21] }\end{array}$} & \multirow{4}{*}{ Not applicable } & My existing method: \\
\hline & & COST1: is time consuming. \\
\hline & & COST2: is burdensome. \\
\hline & & COST3: is costly. \\
\hline
\end{tabular}

INT1: I intend to continue using the application to track remedies, movements, and compliance requirements on the farm.

Intention to Continue Using/Adopt [14]
INT2U: I predict I will continue using the application to track remedies, movements and compliance requirements on the farm.

INT3U: I plan to continue using the application to track remedies, movements and compliance requirements on the farm.
INT1: I intend to use the application to track remedies, movements, and compliance requirements on the farm

INT2: I predict I will use the application to track remedies, movements and compliance requirements on the farm

ITN3: I plan to use the application to track remedies, movements and compliance requirements on the farm.

\section{References}

1. Jahanmir, S.F.; Cavadas, J. Factors affecting late adoption of digital innovations. J. Bus. Res. 2018, 88, 337-343. [CrossRef]

2. Son, M.; Han, K. Beyond the technology adoption: Technology readiness effects on post-adoption behavior. J. Bus. Res. 2011, 64, 1178-1182. [CrossRef]

3. Rieple, A.; Snijders, S. The role of emotions in the choice to adopt, or resist, innovations by Irish dairy farmers. J. Bus. Res. 2018, 85, 23-31. [CrossRef]

4. Choi, H.; Kim, Y.; Kim, J. Driving factors of post adoption behavior in mobile data services. J. Bus. Res. 2011, 64, 1212-1217. [CrossRef] 
5. Ernst, S.; Tucker, M. Perceptions and Adoption of Information Technologies: Implications for Ohio's Produce Industry in the New Economy; Working Paper Series, AEDE-WP-0016-01; The Ohio State University, Division of Agricultural, Environmental, and Development Economics: Columbus, OH, USA, 2001.

6. Gelb, E.; Schiefer, G.; Parker, C.; Rosskopf, K.; Sieberichs, H. Why is me 11 adoption rate by farmers so slow? (Summary of the EFITA'99 conference question-naire and discussion). Zeitschrift für Agrarinformatik 2000, 4, 79-83.

7. Hennessy, T.; Läpple, D.; Moran, B. The digital divide in farming: a problem of access or engagement? Appl. Econ. Perspect. Policy 2016, 38, 474-491. [CrossRef]

8. McGrath, C.; Zell, D. The future of innovation diffusion research and its implications for management: A conversation with Everett Rogers. J. Manag. Inq. 2001, 10, 386-391. [CrossRef]

9. Teagasc. Technology Foresight 2035; Teagasc: Carlow, Ireland, 2016.

10. Aboal, D.; Mondelli, M.; Vairo, M. Innovation and productivity in agricultural firms: evidence from a country-wide farm-level innovation survey. Econ. Innov. New Technol. 2019, 28, 616-634. [CrossRef]

11. Tashakkori, A.; Johnson, R.B.; Teddlie, C. Foundations of Mixed Methods Research: Integrating Quantitative and Qualitative Approaches in the Social and Behavioral Sciences; Sage Publications: Thousand Oaks, CA, USA, 2020.

12. Rogers, E.M. Diffusion of Innovations: Modifications of a model for telecommunications. In Die Diffusion von Innovationen in der Telekommunikation; Springer: Berlin/Heidelberg, Germany, 1995; pp. 25-38.

13. Legris, P.; Ingham, J.; Collerette, P. Why do people use information technology? A critical review of the technology acceptance model. Inf. Manag. 2003, 40, 191-204. [CrossRef]

14. Venkatesh, V.; Morris, M.G.; Davis, G.B.; Davis, F.D. User acceptance of information technology: Toward a unified view. MIS Q. 2003, 27, 425-478. [CrossRef]

15. Ajzen, I. The theory of planned behavior. Organ. Behav. Hum. Decis. Process. 1991, 50, 179-211. [CrossRef]

16. Fishbein, M.; Ajzen, I. Belief, attitude, intention, and behavior: An introduction to theory and research. Philos. Rhetor. 1977, 10, 130-132.

17. Davis, F.D. Perceived usefulness, perceived ease of use, and user acceptance of information technology. MIS Q. 1989, 13, 319-340. [CrossRef]

18. Li, H.; Gupta, A.; Zhang, J.; Sarathy, R. Examining the decision to use standalone personal health record systems as a trust-enabled fair social contract. Decis. Support Syst. 2014, 57, 376-386. [CrossRef]

19. Bhattacherjee, A. Understanding information systems continuance: An expectation-confirmation model. MIS Q. 2001, 25, 351-370. [CrossRef]

20. Polites, G.L.; Karahanna, E. Shackled to the status quo: The inhibiting effects of incumbent system habit, switching costs, and inertia on new system acceptance. MIS Q. 2012, 36, 21-42. [CrossRef]

21. Recker, J. Reasoning about discontinuance of information system use. Neuropsychol. Rev. 2016, $17,24166$.

22. Putler, D.S.; Zilberman, D. Computer use in agriculture: evidence from Tulare County, California. Am. J. Agric. Econ. 1988, 70, 790-802. [CrossRef]

23. Mishra, A.; Wilson, C.; Williams, R. Factors affecting financial performance of new and beginning farmers. Agric. Financ. Rev. 2009, 69, 160-179. [CrossRef]

24. Ascough, J.; Hoag, D.; McMaster, G.; Frasier, W. Computer use and satisfaction by great plains producers: ordered logit model analysis. Agron. J. 2002, 94, 1263-1269. [CrossRef]

25. Nikkilä, R.; Seilonen, I.; Koskinen, K. Software architecture for farm management information systems in precision agriculture. Comput. Electron. Agric. 2010, 70, 328-336. [CrossRef]

26. McDonald, R.; Heanue, K.; Pierce, K.; Horan, B. Factors influencing new entrant dairy farmer's decision-making process around technology adoption. J. Agric. Educ. Ext. 2016, 22, 163-177. [CrossRef]

27. Gloy, B.A.; LaDue, E.L. Financial management practices and farm profitability. Agric. Financ. Rev. 2003, 63, 157-174. [CrossRef]

28. Gloy, B.A.; Akridge, J.T. Computer and internet adoption on large US farms. Int. Food Agribus. Manag. Rev. 2000, 3, 323-338. [CrossRef]

29. Hoag, D.L.; Ascough, J.C.; Frasier, W.M. Farm computer adoption in the Great Plains. J. Agric. Appl. Econ. 1999, 31, 57-67. [CrossRef]

30. Hew, J.J.; Lee, V.H.; Ooi, K.B.; Wei, J. What catalyses mobile apps usage intention: an empirical analysis. Ind. Manag. Data Syst. 2015, 115, 1269-1291. [CrossRef]

31. Central Statistics Office. Farm Structure Survey 2013; Central Statistics Office: Cork, Ireland, 2013.

32. Hong, W.; Thong, J.Y. Internet privacy concerns: An integrated conceptualization and four empirical studies. MIS Q. 2013, 37, 275-298. [CrossRef]

33. MacKenzie, S.B.; Podsakoff, P.M.; Podsakoff, N.P. Construct measurement and validation procedures in MIS and behavioral research: Integrating new and existing techniques. MIS Q. 2011, 35, 293-334. [CrossRef]

34. Hair, J.F. Multivariate Data Analysis; Springer: Berlin/Heidelberg, Germany, 2009.

35. Henseler, J.; Hubona, G.; Ray, P.A. Using PLS path modeling in new technology research: Updated guidelines. Ind. Manag. Data Syst. 2016, 116, 2-20. [CrossRef] 
36. Fornell, C.; Larcker, D.F. Evaluating structural equation models with unobservable variables and measurement error. J. Mark. Res. 1981, 18, 39-50. [CrossRef]

37. Raykov, T. Estimation of composite reliability for congeneric measures. Appl. Psychol. Meas. 1997, 21, 173-184. [CrossRef] 